\title{
Liberalisation and Market Concentration Impact on Performance of the Non-Life Insurance Industry: The Evidence from Eastern Europe
}

\author{
Vladimir Njegomir ${ }^{\mathrm{a}}$ and Dragan Stojic ${ }^{\mathrm{b}}$ \\ ${ }^{a}$ Faculty of Legal and Business Studies, 14 Sonja Marinkovic, 21000 Novi Sad, Serbia. \\ E-mail: njega@eunet.rs \\ ${ }^{\mathrm{b}}$ Faculty of Economics, 16 Dr Sime Milosevica, 21000 Novi Sad, Serbia. \\ E-mail: stojicd@ef.uns.ac.rs
}

The aim of this paper is to examine market structure, conduct and performance relationship (S-C-P) hypothesis for the non-life insurance industry in Eastern European countries. Additionally, we examine the effect of liberalisation on market structure and performance. We use the country-specific fixed effects models for panel data for the period 2004-2008 allowing each cross-sectional unit to have a different intercept term serving as an unobserved random variable that is potentially correlated with the observed regressors. Three models are presented, each placing market structure, liberalisation and profitability in a distinct environment defined by related control variables. The research results support the S-C-P hypothesis in all of the observed models, showing evidence of strong influence of market structure and liberalisation on market profitability. These results could be useful in decision-making for both governments and insurance companies.

The Geneva Papers (2011) 36, 94-106. doi:10.1057/gpp.2010.32

Keywords: non-life insurance; market structure; profitability; Eastern Europe

\section{Introduction}

Although there are differences in the stage of the process of accession to the EU and the level of development, Eastern European countries have similar political, cultural and social backgrounds. Historically, insurance markets of these countries have imposed significant barriers to entry, have been monopolistic, strictly regulated and government-dominated in the provision of insurance services. As universal access to health care, pensions and survivor benefits have been based on public funds, "private insurance was neither much needed nor purchased". "However, in the last 20 years these countries have passed through the transition process, from planned to free market economies. Economic development was followed by the development of the insurance market. Among the most important developments have been privatisation of state-owned insurance companies, reduction of barriers to trade and market liberalisation. These changes and the general trend towards global markets and risks eased the entrance of many foreign insurance companies in Eastern European insurance markets. As a result of these changes and the increase in economic values and income, insurance markets of these countries have marked considerable growth.

\footnotetext{
${ }^{1}$ Dorfman (2008, p. 76).
} 
The structure-conduct-performance (S-C-P) paradigm was developed by Mason ${ }^{2}$ and Bain. ${ }^{3}$ It was the dominant paradigm in industrial organisation and later transition to strategic management is attributed to Porter. The paradigm implies that market performance is determined by market conduct, which in turn directly and indirectly depends on market structure. Market structure is characterised by features such as number of companies and their market shares, entry barriers and price elasticity of demand. Business conduct refers to market behaviour of companies, which can vary from collusive to competitive. Market performance is indicated by factors such as profitability, efficiency and market growth. According to the S-C-P hypothesis, higher profitability in any market is associated with anti-competitive behaviour induced by higher market concentration. Additionally, the existence of entry barriers reduces economic welfare, ${ }^{4}$ which can be optimal only in the presence of perfectly competitive markets. ${ }^{5}$ Thus, analysis of the market structure, business conduct and performance relationship can facilitate optimal strategy decisions and devising competition laws, designed to modify or prevent market structures that are linked with poor economic performance. ${ }^{6}$

It is well established that liberalisation and privatisation facilitates the admission of foreign insurers that bring financial strength, know-how and managerial expertise that facilitate market development and competitiveness (e.g., Puri; ${ }^{7}$ Dorfman ${ }^{1}$ ). However, there is relatively little research on the issue of market concentration and liberalisation relationship with profitability in non-life insurance. The available research on market concentration and profitability relationship is mainly focused on the U.S. insurance market with inconsistent results (e.g., Joskow; ${ }^{8}$ Carroll; ${ }^{9}$ Chidambaran et al. $;^{10}$ Bajtelsmit and Bouzouita; ${ }^{11}$ Choi and Weiss; ${ }^{12}$ Pope and $\mathrm{Ma}^{13}$ ).

To our knowledge, the research focusing on the issue of complex relationships among liberalisation, market concentration and profitability of non-life insurance markets in Eastern European countries is non-existent. The absence of any study regarding the region and observed inconsistency in existing papers encouraged us to pursue the in-depth analysis of the problem.

The changes in profitability influenced by changes in market structure impose great challenges to domestic and foreign insurers regarding their business operations and strategies. For example, Berry-Stölzle et al. ${ }^{14}$ found that successful business strategies for insurers in emerging markets vary across countries when they control for country-level

\footnotetext{
${ }^{2}$ Mason (1939).

${ }^{3}$ Bain (1951).

${ }^{4}$ Bain (1956).

${ }^{5}$ Samuelson (1965).

${ }^{6}$ Ferguson and Ferguson (1994).

${ }^{7}$ Puri (2007).

${ }^{8}$ Joskow (1973).

${ }^{9}$ Carroll (1993).

${ }^{10}$ Chidambaran et al. (1997).

11 Bajtelsmit and Bouzouita (1998).

12 Choi and Weiss (2005).

${ }^{13}$ Pope and Ma (2008).

14 Berry-Stölzle et al. (2010).
} 
economic and market characteristics. Also, the insight into this relationship is important for governments that aim to achieve for insurance to be available and affordable for all (e.g. Rejda $;{ }^{15}$ Dorfman ${ }^{1}$ ) and "to mitigate the impact of significant market imperfections". ${ }^{16}$ The aim of this paper is to facilitate decisions concerned with market development and competitiveness, on company and government level, by investigating the relationship among liberalisation, market concentration and profitability of the non-life insurance market in Eastern Europe.

We apply linear country-specific fixed effects model for panel data. Panel data encompasses 11 formerly communist European states outside the Soviet Union for the period 2004-2008. ${ }^{17}$ The rationale for focusing on these countries is their common socioeconomic state during the communist era. After the fall of the Berlin wall, all these countries shifted to market economies and democratic political systems. During the period 2004-2008 non-life insurance industry of these countries flourished as a result of strong economic growth, regulatory reforms and involvement in the EU integration processes. Countries that belonged to the former Soviet Union are excluded due to absence of relevant data. We have chosen fixed effects due to a small number of control variables in each of the three models for capturing the effects of unobserved variables that are potentially correlated with the observed regressors.

The remainder of this paper is organised as follows. The next section reviews the prior literature on the issue of S-C-P paradigm in insurance. The subsequent section presents the theoretical framework of the research, while the fourth section presents the data and methodology applied in the analysis. The penultimate section encompasses presentation of the empirical results, and the final section concludes.

\section{Prior literature review}

Most of the studies of the S-C-P hypothesis refer to the banking industry. The existing research literature of S-C-P hypothesis in insurance industry is relatively scarce. Additionally, it is mainly focused on the U.S. insurance market and the results of these studies are inconsistent.

One of the first researchers in the insurance industry that studied S-C-P hypothesis was Joskow. ${ }^{8}$ Examining the U.S. non-life insurance industry competitive structure, he found that despite the competitive market structure, insurers set prices through cartellike rating bureaus. He concludes that the combination of state regulation, cartel pricing and other legal peculiarities has resulted in the use of an inefficient sales technique, supply shortages and over-capitalisation.

Many subsequent studies found support for the S-C-P hypothesis. Chidambaran et al. ${ }^{10}$ empirically analysed the economic performance across 18 different lines of the

${ }^{15}$ Rejda (2005).

${ }^{16}$ Harrington and Niehaus (2004, p. 106).

${ }^{17}$ Countries included in our analysis are Bosnia and Herzegovina, Croatia, Former Yugoslav Republic of Macedonia, Slovenia and Serbia. Montenegro was omitted due to lack of relevant available data. Former Eastern Bloc countries are the following: Hungary, Czech Republic, Slovakia, Romania, Bulgaria and Poland. 
U.S. property-liability insurance industry with major emphasis on the pricing of insurance and the cost of producing insurance. Using data for the 1984-1993 period, they found that higher concentration leads to the reduced level of pricing rivalry. Bajtelsmit and Bouzouita ${ }^{11}$ analysed the relationship between performance and market structure in the private passenger automobile insurance market in the United States for the period 1984-1992 and found evidence of a positive relationship between market concentration and profitability. Pope and $\mathrm{Ma}^{13}$ examined the complex relationship between liberalisation, market concentration and profitability using regression methodology on the sample of 23 countries during the period 1996-2003. Analysing determinants of foreign participation in life insurance markets across 24 OECD countries during the period 1993-2000, Ye et al. ${ }^{18}$ found that level of competition and market liberalisation, among other determinants, have positive impacts on foreign participation in life insurance markets.

However, several research papers found no support for the S-C-P hypothesis. Carroll $^{9}$ examined the relationship between market structure and performance of the U.S. workers' compensation insurance using data for the period 1980-1987. Choi and Weiss $^{12}$ investigated the relationships between market structure and performance in property-liability insurers in the United States over the period 1992-1998. Using data for 52 Austrian insurance companies for 2003, Jedlicka and Jumah ${ }^{19}$ examined whether higher market concentration led to anti-competitive behaviour and thus higher profitability. Liebenberg and Kamerschen ${ }^{20}$ examined the South African auto insurance market using data for the period 1980-2000.

The lack of consistency of the previous research results at the international level and the lack of similar study for the Eastern European insurance industry served us as a motivator for the analysis on the topic. ${ }^{21}$ While the main contribution of the research presented in this paper is original, as it presents the first study of S-C-P relationship in the non-life insurance industry for Eastern European countries, it also contains results that extend and complement those in existing literature on the S-C-P paradigm related to the insurance industry.

\section{Theoretical framework}

Porter $^{22}$ created a framework for analysing companies' competitive advantage and market power at industry or market levels using five market forces (elements of market structure): industry (market) rivalry, threat of entry, threat of substitutes, bargaining power of suppliers and bargaining power of buyers. As market structure is considered to be the predominant determinant of relative market power and level of profit the company can generate, the five forces model is intended to be used for analysing the

${ }^{18}$ Ye et al. (2009).

19 Jedlicka and Jumah (2006).

${ }^{20}$ Liebenberg and Kamerschen (2008).

${ }^{21}$ Although three additional hypotheses emerged, the most tested, especially in the banking industry, being efficient structure hypothesis that requires firm-specific examination (see Choi and Weiss, 2005), we limit our discussion to S-C-P hypothesis.

${ }^{22}$ Porter (1980). 
market structure and selecting a strategy that is appropriate to that structure. As this model is universal for all industries, it is applicable to the analysis of the S-C-P paradigm in the context of the non-life insurance market (see Massey et al.). ${ }^{23}$

Insurance market encompasses insureds, insurers and intermediaries. It is specific in relation to other markets in the fact that insureds are simultaneously buyers of insurance and suppliers of capital to insurance companies, but their bargaining power in both roles is weak. ${ }^{13}$ As bargaining power of suppliers and bargaining power of buyers have little impact on insurance markets, the remaining three market forces will be the subject of our empirical examination. Additionally, we observe government regulation and the state of development of national economy.

We use the insurer's profit margin as defined by Carroll: ${ }^{9}$

$$
\frac{\Pi}{R}=\frac{\frac{\text { Profit }}{\text { Revenue }}=(\text { Premiums }- \text { Losses }- \text { Expenses }+ \text { Investments })}{\text { Premiums }=1-L R-E R+R O I,}
$$

where $L R$ is loss ratio, $E R$ is expense ratio and $R O I$ is return on investment. Premiums observed are gross written premiums. Our measure of market profitability $(P R)$ is proxied by $1-L R-E R$. Owing to the lack of information on investment activities we observe the difference between long-term interest rate and inflation rate $(R O I)$ as a control variable, instead of return on investment.

Market rivalry between established companies, measured by the degree of concentration, is the central force in Porter's ${ }^{22}$ examination of factors of competitive advantage. We measure concentration ratio $(C R)$ as a ratio of market shares of the five largest companies in each national market. As the S-C-P paradigm implies that higher concentration leads to monopoly (higher) profits, we hypothesise the positive impact of concentration to profitability.

We measure market rivalry by the number of companies operating in the market $(C O M)$. The latter ought to compete for the same customers and resources. It is held that rivalry intensifies if a larger number of companies are present in the market. On the basis of previous research in insurance-related literature (e.g., Outreville; ${ }^{24}$ Pope and $\mathrm{Ma}^{13}$ ) we hypothesise a negative relationship between the number of insurers in the market and profitability.

Threat of entry relates to the degree of easiness for new competitors to enter the market. Previous research (e.g., Bain $;{ }^{4}$ Joskow $^{8}$ and Porter $^{22}$ ) indicates that the larger the barriers to entry, the more monopolistic prices would be charged and thus greater profitability obtained. To control for this influence we use Index of Economic Freedom $(L I B)$. This is the first time this index is used in a study on the impact of liberalisation in insurance markets. The variable assesses each national market on a scale of $0-100$, where higher values indicate a more liberalised environment. In order to determine synergetic effect of market concentration and liberalisation we include the interaction term between these variables $(C R L I B) .{ }^{25}$

\footnotetext{
23 Massey et al. (2005).

${ }^{24}$ Outreville (2007).

${ }^{25} C R L I B$ is obtained by multiplying $C R$ with $L I B$.
} 
Insurance is generally held as a unique product for risk transfer. Although alternatives exist, like transferring of risks to capital markets or self-insuring by captive companies formation, their use is still limited in scope. ${ }^{26}$ The only real alternative for insurance products is to restrain from buying them. We measure threat of substitutes by price elasticity of demand $(E L) .{ }^{27}$ We proxy the demand by using individual national market's insurance density (aggregate gross premium/population) and market price by using the inverse of loss ratio (for similar use see Meier; ${ }^{28}$ Pope and $\mathrm{Ma}^{13}$ ). Following theoretical contributions of Cowling and Waterson ${ }^{29}$ and Dorfman, ${ }^{1}$ and empirical evidence, ${ }^{30}$ we hypothesise a negative relationship between price elasticity of demand for insurance and profitability.

The insurance market is regulated, to a certain degree, in every country. Although in a perfect world regulations should be equivalent across jurisdictions, ${ }^{31}$ in reality they vary. However, even countries with the most deregulated insurance market regulate the solvency position of insurers. ${ }^{32}$ Heavily regulated insurance markets are considered those where the government regulates product pricing and content. To control for government regulation we use binary variable $(R E G) .{ }^{33}$ As previous research has not reached the consensus, we do not hypothesise the expected relationship between regulation and profitability.

Empirical evidence ${ }^{30}$ implies that insurance demand varies with the level of gross domestic product (GDP). ${ }^{34}$ For the impact of the economy $(E C)$ on insurance market profitability we control by using the natural logarithm of GDP per capita, yet do not hypothesise the underlining relationship.

Finally, following Pope and $\mathrm{Ma}^{13}$ we include additional variable $(A L)$ to control for the auto insurance lines because these lines have the largest share in non-life insurance premiums in all observed countries.

\section{Data and methodology}

Our data covers 11 countries, five of which were formerly constituent republics of Socialist Federal Republic of Yugoslavia, and six countries of the former Eastern Block, over the time period 2004-2008. The number of observations for each country varies between 3 and 5 depending on data availability. Descriptive statistics for each variable depicting market concentration, liberalisation and profitability relationship as well as expected signs of relationship are shown in Table 1.

During the period 2004-2008 profitability shows decline in most of the observed countries. The decline to negative profitability was marked in Hungary and Serbia in

\footnotetext{
${ }^{26}$ Njegomir (2009).

${ }^{27}$ Relative change of demand ( $\delta$ Demand) is defined as $\left(\right.$ Demand $_{t+1}-$ Demand $\left._{t}\right) /$ Demand $_{t} \delta$ Price is defined in an analogous way.

${ }^{28}$ Meier (2006).

${ }^{29}$ Cowling and Waterson (1976).

${ }^{30}$ Swiss Re (1993).

${ }^{31}$ Flamee and Windels (2009).

32 Skipper and Kwon (2007, p. 624).

${ }^{33} \mathrm{We}$ assign 0 to insurance markets where product pricing is not explicitly regulated and 1 otherwise.

${ }^{34}$ For a review of research studies that found support for this relationship, see Hussels et al. (2005).
} 
The Geneva Papers on Risk and Insurance-Issues and Practice

100

Table 1 Descriptive statistics and expected signs of relationship

\begin{tabular}{lcccccccc}
\hline Variable & $\begin{array}{c}\text { Expected } \\
\text { sign }\end{array}$ & Mean & Median & Maximum & Minimum & $\begin{array}{c}\text { Standard } \\
\text { deviation }\end{array}$ & Skewness & Kurtosis \\
\hline PR & & 0.158329 & 0.15061 & 0.401661 & -0.05297 & 0.12212 & 0.25043 & 2.12587 \\
AL & \pm & 0.573833 & 0.5728 & 0.741507 & 0.36803 & 0.10512 & -0.2493 & 2.27477 \\
COM & - & 22.4359 & 20 & 46 & 9 & 9.80009 & 0.80774 & 2.65127 \\
CR & + & 0.776706 & 0.81547 & 0.964 & 0.4324 & 0.14339 & -1.16878 & 3.4344 \\
CRLIB & \pm & 45.25297 & 45.2393 & 57.95154 & 19.3551 & 10.062 & -0.92085 & 3.31129 \\
EC & \pm & 8.816507 & 8.98814 & 9.847071 & 7.80125 & 0.66243 & -0.1132 & 1.6261 \\
EL & - & 7.174807 & 0.47344 & 147.8461 & -21.948 & 32.6626 & 3.7903 & 16.2735 \\
LIB & \pm & 57.99231 & 59.2 & 67.4 & 44.7 & 5.99379 & -0.42857 & 2.34237 \\
REG & \pm & 0.487179 & 0 & 1 & 0 & 0.50637 & 0.0513 & 1.00263 \\
ROI & \pm & 0.022924 & 0.02271 & 0.098 & -0.03904 & 0.02926 & 0.2087 & 3.3606 \\
\hline
\end{tabular}

Source: authors' calculations.

the last two years of the observed period. The exception is the non-life insurance industry in Bosnia and Herzegovina with recorded profitability of over 40 per cent during 2008. The number of companies throughout the region remained relatively constant during the whole period. The minimal number of nine companies was recorded in FYR Macedonia while the maximum number of companies of 46 was marked in the Czech Republic. Concentration ratio remains relatively constant during the observed period. The least concentrated market was in Bosnia and Herzegovina while the most concentrated market was in Slovenia. The Index of Economic Freedom and GDP per capita shows mild increase throughout the region during the observed period.

The data is obtained from various sources. Premium, loss, expense, market share of first five and total number of insurance companies' data are obtained from individual countries' regulatory bodies and national insurance associations. Inflation rate, population and GDP data is obtained from the European Bank for Research and Development (EBRD), economic statistics and forecasts published for each year in Transition Report. Population data for countries of ex-Yugoslavia are obtained from individual countries' statistical offices, except for Bosnia and Herzegovina, for which we use EBRD's estimates of total population excluding refugees abroad. Long-term interest rate is obtained from the United Nations Economic Commission for Europe (UNECE) Statistical Division Database. Index of economic freedom data, that depicts threat of new entrants, is obtained from The Heritage Foundation. Finally, exchange rate data of national currencies against the Euro is obtained from the European Central Bank and individual countries' central banks, for countries that are not members of the EU. All monetary values have been denominated to the 2008 Euro value and adjusted for inflation by authors.

Given the cross-sectional and time-series data, we use country-specific fixed effects panel regression model with common coefficients across all cross-section members of the pool. The general equation to be estimated using pooled least squares is:

$$
y_{i t}=\alpha_{i}+\mathbf{x}_{i t} \beta+u_{i t},
$$


where $y_{i t}$ is a scalar dependent variable, that is, profitability, $\mathbf{x}_{i t}$ is a $K \times 1$ vector of independent variables, $u_{i t}$ is a scalar disturbance term, $i$ indexes country in a cross section, and $t$ indexes time measured in years. Since the error terms $u_{i t}$ are potentially serially correlated and heteroskedastic, we propose an autoregressive process of first order: $u_{i t}=\rho u_{i t-1}+e_{i t}$, where $e_{i t}$ is white noise. The model incorporates White's consistent covariance matrix, ${ }^{35}$ for dealing with heteroskedasticity.

Model 1 incorporates the state of the economy and its return on investment as environment in which we observe influences of market liberalisation and concentration on overall profitability. Namely, we estimate the equation:

$$
\begin{aligned}
(P R)_{i t}= & \alpha_{i}+\beta_{1}(C R)_{i t}+\beta_{2}(L I B)_{i t} \\
& +\beta_{3}(C R L I B)_{i t}+\beta_{4}(E C)_{i t} \\
& +\beta_{5}(R O I)_{i t}+u_{i t} .
\end{aligned}
$$

Model 2 focuses on testing S-C-P hypothesis through the prism of competitors and threat of substitutes:

$$
\begin{aligned}
(P R)_{i t}= & \alpha_{i}+\beta_{1}(C R)_{i t}+\beta_{2}(L I B)_{i t} \\
& +\beta_{3}(C R L I B)_{i t}+\beta_{4}(C O M)_{i t} \\
& +\beta_{5}(E L)_{i t}+u_{i t} .
\end{aligned}
$$

Finally, Model 3 tests the S-C-P hypothesis while observing regulatory constraints on insurance companies imposed by governments, as well as the most dominant lines of insurance in each company. The equation and parameters to be estimated are given by:

$$
\begin{aligned}
(P R)_{i t}= & \alpha_{i}+\beta_{1}(C R)_{i t}+\beta_{2}(L I B)_{i t} \\
& +\beta_{3}(C R L I B)_{i t}+\beta_{4}(A L)_{i t} \\
& +\beta_{5}(R E G)_{i t}+u_{i t} .
\end{aligned}
$$

\section{Empirical results}

The models used in this study have been introduced at the end of the previous chapter. In this section we present original results and interpretations concerning all the observed models. Model 1 focuses on explanatory variables of S-C-P hypothesis when influenced by the state of the economy.

The results of the empirical analysis for Model 1 are presented in Table 2.

\footnotetext{
${ }^{35}$ White (1980).
} 
Table 2 Parameter estimates from Model 1

\begin{tabular}{|c|c|c|c|c|}
\hline Variable & Coefficient & Std. error & t-Statistic & Prob. \\
\hline $\mathrm{CR}$ & 2.106342 & 0.781697 & 2.694575 & 0.0113 \\
\hline LIB & 0.022706 & 0.006566 & 3.458352 & 0.0016 \\
\hline CRLIB & -0.040953 & 0.014159 & -2.892310 & 0.0069 \\
\hline $\mathrm{EC}$ & -0.126780 & 0.155985 & -0.812766 & 0.4226 \\
\hline ROI & -0.406504 & 0.406311 & -1.000475 & 0.3248 \\
\hline$R$-squared & 0.869219 & \multicolumn{2}{|c|}{ Mean dependent var } & 0.151564 \\
\hline Adjusted $R$-squared & 0.805938 & \multicolumn{2}{|c|}{ SD dependent var } & 0.130539 \\
\hline $\mathrm{SE}$ of regression & 0.057506 & \multicolumn{2}{|c|}{ Sum squared resid } & 0.102513 \\
\hline F-statistic & 51.50932 & \multicolumn{2}{|c|}{ Durbin-Watson stat } & 2.001921 \\
\hline Prob(F-statistic) & 0.000000 & & & \\
\hline
\end{tabular}

Source: authors' calculations.

Note: Dependent Variable: PR. Country-specific intercepts have been omitted from the table.

The coefficients of key variables, market concentration $(C R)$ and liberalisation $(L I B)$, all have positive signs and are statistically significant at five per cent level. Additionally, partial correlation coefficient between $C R$ and $L I B$ is strongly negative. Treating the $L I B$ as an exogenous variable, we find that the increase in $L I B$ decreases $C R$. Thus, with an increase of liberalisation the overall profitability decreases, as a result of reduced collusive behaviour of market competitors. These results are consistent with previous studies that found support for the S-C-P hypothesis (e.g., Chidambaran et al: ${ }^{10}$ Bajtelsmit and Bouzouita: ${ }^{11}$ Pope and $\left.\mathrm{Ma}^{13}\right)$.

Both the return of investment (ROI) and strength of economy $(E C)$ have a negative sign, but are statistically insignificant.

Recall that Model 2 observes the influence of market liberalisation and concentration on profitability, with respect to the number of competitors in the market and the substitution threat.

The results of the empirical analysis for Model 2 are presented in Table 3.

The coefficients of key variables are significant at five per cent level. As with the previous model, the partial correlation coefficient between $C R$ and $L I B$ is strongly negative. Thus, the empirical results of Model 2 support the S-C-P hypothesis.

Both control variables, namely Elasticity $(E L)$ and number of competitors (COM), are found to be positive, but insignificant.

The focus of interest in Model 3 was to test the S-C-P hypothesis through the prism of governments' regulations imposed on insurance companies with respect to auto lines as dominant lines in each of the companies.

The results of the empirical analysis for Model 3 are presented in Table 4.

The coefficients of key variables, market concentration $(C R)$ and liberalisation $(L I B)$ have positive signs and are statistically significant at one per cent level. As with previous models, the partial correlation coefficient between $(C R)$ and $(L I B)$ is strongly negative. The auto lines, as the remaining control variable, is found to have a positive impact on profitability, yet is not found to be statistically significant at five per cent level. However, regulation is found to have a positive influence and is statistically significant at ten per cent level. The results support the S-C-P hypothesis. 
Table 3 Parameter estimates from Model 2

\begin{tabular}{|c|c|c|c|c|}
\hline Variable & Coefficient & Std. error & t-Statistic & Prob. \\
\hline CR & 2.013919 & 0.739417 & 2.723660 & 0.0116 \\
\hline LIB & 0.023664 & 0.008385 & 2.822053 & 0.0092 \\
\hline CRLIB & -0.046018 & 0.015743 & -2.923107 & 0.0073 \\
\hline COM & 0.000550 & 0.004975 & 0.110583 & 0.9128 \\
\hline EL & $3.72 \mathrm{E}-05$ & 0.000269 & 0.138614 & 0.8909 \\
\hline$R$-squared & 0.876723 & \multicolumn{2}{|c|}{ Mean dependent var } & 0.159415 \\
\hline Adjusted $R$-squared & 0.802757 & \multicolumn{2}{|c|}{ SD dependent var } & 0.119866 \\
\hline $\mathrm{SE}$ of regression & 0.053235 & \multicolumn{2}{|c|}{ Sum squared resid } & 0.070849 \\
\hline$F$-statistic & 44.44880 & \multicolumn{2}{|c|}{ Durbin-Watson stat } & 2.084161 \\
\hline $\operatorname{Prob}(F$-statistic $)$ & 0.000000 & & & \\
\hline
\end{tabular}

Source: authors' calculations.

Note: Dependent Variable: PR. Country-specific intercepts have been omitted from the table.

Table 4 Parameter estimates from Model 3

\begin{tabular}{|c|c|c|c|c|}
\hline Variable & Coefficient & Std. error & $t$-Statistic & Prob. \\
\hline $\mathrm{CR}$ & 2.751439 & 0.807869 & 3.405799 & 0.0018 \\
\hline LIB & 0.027963 & 0.007977 & 3.505413 & 0.0014 \\
\hline CRLIB & -0.055996 & 0.015663 & -3.574916 & 0.0011 \\
\hline $\mathrm{AL}$ & 0.235186 & 0.325580 & 0.722361 & 0.4753 \\
\hline REG & 0.062436 & 0.033416 & 1.868435 & 0.0709 \\
\hline$R$-squared & 0.848949 & \multicolumn{2}{|c|}{ Mean dependent var } & 0.147183 \\
\hline Adjusted $R$-squared & 0.778144 & \multicolumn{2}{|c|}{ SD dependent var } & 0.123741 \\
\hline $\mathrm{SE}$ of regression & 0.058284 & \multicolumn{2}{|c|}{ Sum squared resid } & 0.108704 \\
\hline$F$-statistic & 44.96225 & \multirow{2}{*}{\multicolumn{2}{|c|}{ Durbin-Watson stat }} & 2.045625 \\
\hline $\operatorname{Prob}(F$-statistic $)$ & 0.000000 & & & \\
\hline
\end{tabular}

Source: authors' calculations.

Note: Dependent Variable: PR. Country-specific intercepts have been omitted from the table.

We use estimated coefficients of Model 1 to plot the 3D image, represented by Figure 1, to illustrate the effects of market concentration and liberalisation on market profitability, ceteris paribus. We notice that for low levels of liberalisation (A-B), concentration has a mild, yet positive impact on profitability, which is in support of S-C-P. However, as level of liberalisation increases (A-C), we see that at the most liberalised levels, the increase in market concentration actually has a negative impact on profitability (C-D).

\section{Conclusion}

This research study examines the relationships among market structure, liberalisation and performance in the property-liability market of the five countries of the exYugoslavia region and six countries of the former Eastern Block for the period covering 


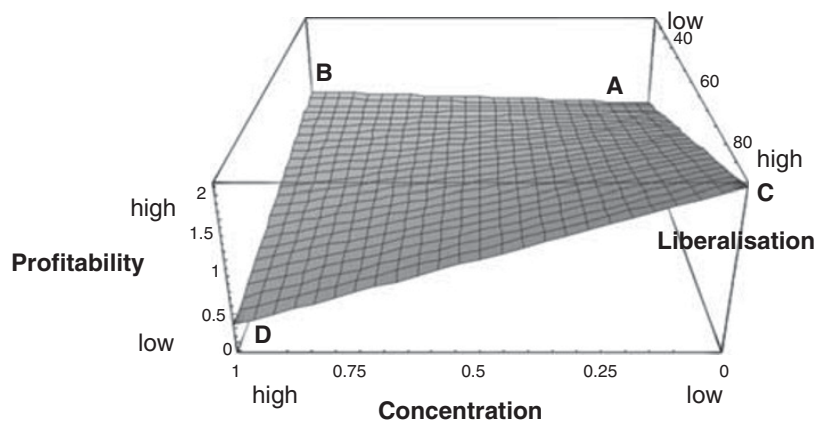

Figure 1. 3D plot in profitability-concentration-liberalisation space. Source: authors' calculations.

2004-2008. The examination encompasses non-life insurance industries in 11 countries: Bosnia and Herzegovina, Croatia, FYR Macedonia, Serbia, Slovenia, Hungary, Slovakia, Czech Republic, Poland, Romania and Bulgaria. We use three models for capturing influences of market structure and liberalisation on market profitability. The S-C-P hypothesis is tested from three distinct points of interest. Firstly, market structure, liberalisation and performance are put in relation with the strength of the economy and corresponding rate of return. Model 2 connects the former with the number of competitors and the substitution threat. Finally, Model 3 uses governments' regulations and dominant lines of insurance business as control variables.

The research results of all three models show support for the S-C-P hypothesis. These results are important for governments that wish to achieve affordable and available insurance for all. Governments interfere in insurance markets by procompetitive and pro-liberalising policies. Our findings could facilitate their decisionmaking as they suggest that greater liberalisation influences the decrease in concentration and an indirect decrease in profitability, thus providing the achievement of greater social welfare. Additionally, research results could provide insurance companies with a useful comparison across different national markets in Eastern Europe, thus enabling them to formulate optimal competitive strategies. Furthermore, companies would be able to anticipate consequences of changes in government policies.

Possible limitation of the research results could be the insignificance of most of the control variables appearing in models. Additionally, the implications of the results related to short-term changes in market structure have not been taken into account. Further research should involve testing of alternative hypothesis, namely efficient structure hypothesis, in pursue of higher significance levels of explanatory variables. In addition, further research should include a greater number of countries helping to gain more consistent estimators.

\section{References}

Bain, J.S. (1951) 'Relation of profit-rate to industry concentration: American manufacturing, 1936-1940', Quarterly Journal of Economics 65: 293-324. 
Bain, J.S. (1956) Barriers to New Competition: Their Character and Consequences in Manufacturing Industries, Cambridge, MA: Harvard University Press.

Bajtelsmit, V.L. and Bouzouita, R. (1998) 'Market structure and performance in private passenger automobile insurance', Journal of Risk and Insurance 65(3): 503-514.

Berry-Stölzle, T.R., Hoyt, R.E. and Wende, S. (2010) 'Successful business strategies for insurers entering and growing in emerging markets', The Geneva Papers on Risk and Insurance - Issues and Practice 35(1): $110-128$

Carroll, A.M. (1993) 'An empirical investigation of the structure and performance of the private workers' compensation market', Journal of Risk and Insurance 60(2): 185-207.

Chidambaran, N.K., Pugel, T.A. and Saunders, A. (1997) 'An investigation of the performance of the U.S. property-casualty insurance industry', Journal of Risk and Insurance 64(2): 371-381.

Choi, B.P. and Weiss, M.A. (2005) 'An empirical investigation of market structure, efficiency, and performance in property-liability insurance', Journal of Risk and Insurance 72(4): 635-673.

Cowling, K. and Waterson, M. (1976) 'Price-cost margins and market structure', Economica 43: 267-274.

Dorfman, M.S. (2008) Introduction to Risk Management and Insurance, Upper Saddle River, NJ: Pearson Education, Inc.

Ferguson, P.R. and Ferguson, G.J. (1994) Industrial Economics-Issues and Perspectives, London: Palgrave Macmillan.

Flamée, M. and Windels, P. (2009) 'Restructuring financial sector supervision: Creating a level playing field', The Geneva Papers on Risk and Insurance - Issues and Practice 34(1): 9-23.

Harrington, S.E. and Niehaus, G.R. (2004) Risk Management and Insurance, $2^{\text {nd }}$ Edition New York, NY: The McGraw-Hill Higher Education.

Hussels, S., Ward, D. and Zurbruegg, R. (2005) 'Stimulating the demand for insurance', Risk Management and Insurance Review 8(2): 257-278.

Jedlicka, L. and Jumah, A. (2006) The Austrian insurance industry: A structure, conduct and performance analysis, working paper, Institute for Advanced Studies, Princeton, NJ.

Joskow, P.L. (1973) 'Cartels, competition and regulation in the property-liability insurance industry', Bell Journal of Economics and Management Science 4(2): 375-427.

Liebenberg, A.P. and Kamerschen, D.R. (2008) 'Structure, conduct and performance analysis of the South African auto insurance market: 1980-2000', South African Journal of Economics 76(2): 228-238.

Mason, E.S. (1939) 'Price and production policies of large-scale enterprise', American Economic Review 29: 61-74.

Massey, R., Badal, V., Ball, M., Flower, M., Fulcher, G., Haria, S., Julian, R., Ooi, P., Truong, B., White, G., White, M. and Winter, R. (2005) The application of strategic models to non-life insurance markets, paper presented at $32^{\text {nd }}$ Annual GIRO Convention, Imperial Hotel, Blackpool, Lancashire, UK.

Meier, U.B. (2006) Existence and Causes of Insurance Cycles in Different Countries: Four Empirical Contributions, Bern: Haupt Verlag AG.

Njegomir, V. (2009) 'Traditional and alternative risk transfers as methods of insurance risk management', PhD dissertation. Faculty of Technical Sciences, University of Novi Sad.

Outreville, J.F. (2007) 'Players and driving forces in world insurance services: Locations and governance', in M. Mashayekhi and D. Fernandes (eds.) Trade and Development Aspects of Insurance Services and Regulatory Frameworks, New York, NY: United Nations Conference on Trade and Development, pp. $47-63$.

Pope, N. and Ma, Y. (2008) 'The market structure-performance relationship in the international insurance sector', Journal of Risk and Insurance 75(4): 947-966.

Porter, M.E. (1980) Competitive Strategy: Techniques for Analyzing Industries and Competitors, New York, NY: Free Press.

Puri, L. (2007) 'Introduction to the trade and development aspects of insurance services and regulatory frameworks', in M. Mashayekhi and D. Fernandes (eds.) Trade and Development Aspects of Insurance Services and Regulatory Frameworks, New York, NY: United Nations Conference on Trade and Development, pp. 1-5.

Rejda, G.E. (2005) Principles of Risk Management and Insurance, Upper Saddle River, NJ: Pearson Education, Inc.

Samuelson, P.A. (1965) Foundations of Economic Analysis, Valley Forge, MA: Atheneum. 
Skipper, H.D. and Kwon, W.J. (2007) Risk Management and Insurance: Perspectives in a Global Economy, Oxford: Blackwell Publishing.

Swiss Re (1993) The Effects of Price Adjustment on Insurance Demand, Zurich: Sigma No. 5.

Swiss Re (2009) World Insurance in 2008: Life Premiums Fall in the Industrialised Countries-Strong Growth in the Emerging Economies, Zurich: Sigma No. 3.

White, H. (1980) 'A heteroskedasticity-consistent covariance matrix estimator and a direct test for heteroskedasticity', Econometrica 48: 817-838.

Ye, D., Li, D., Chen, Z., Moshirian, F. and Wee, T. (2009) 'Foreign participation in life insurance markets: Evidence from OECD countries', The Geneva Papers on Risk and Insurance - Issues and Practice 34(3): 466-482.

\section{About the Authors}

Vladimir Njegomir is Assistant Professor for insurance at the Faculty of Legal and Business Studies, Novi Sad. He received his PhD at the Faculty of Technical Sciences, University of Novi Sad. The PhD thesis title was "Traditional and alternative risk transfers as methods of insurance risk management", the BSc thesis was: "Marketing as the basic presumption for the development of insurance and reinsurance" and the MSc thesis was: "Insurance companies as institutional investors". He has eight years of experience in analysing trends in the insurance and the reinsurance industry. He has published more than 70 papers on the issue and has taken active roles in several regional industry meetings.

Dragan Stojić obtained his MSc at the Faculty of Sciences, University of Novi Sad. He is employed as teaching assistant at the Department of Quantitative Methods in Economics, Faculty of Economics Subotica, University of Novi Sad. 